\title{
Analisa Peningkatan Kualitas Layanan Jasa Reparasi Kapal Di Galangan Kapal Jawa Timur
}

\author{
Rani Nurwanti, dan Ir. Triwilaswandio Wuruk Pribadi, M.Sc. \\ Jurusan Teknik Perkapalan, Fakultas Teknologi Kelautan, Institut Teknologi Sepuluh Nopember (ITS) \\ J1. Arief Rahman Hakim, Surabaya 60111 Indonesia \\ e-mail: triwilas@na.its.ac.id
}

\begin{abstract}
Abstrak-Jawa Timur adalah daerah dengan banyak perusahaan galangan kapal dimana layanan jasa reparasi kapal menjadi salah satu jasa utama yang ditawarkan kepada pemilik kapal/perusahaan pelayaran. Kualitas layanan jasa reparasi dan tingkat kepuasan penggunanya sangat mempengaruhi keberlangsungan galangan kapal tersebut. Tujuan dari tugas akhir ini adalah untuk meningkatkan kualitas layanan jasa reparasi kapal berdasarkan penilaian pemilik kapal/perusahaan pelayaran yang pernah melakukan reparasi kapal di galangan kapal yang ada di daerah Jawa Timur. Pertama, dilakukan analisis kepuasan dan penilaian pemilik kapal/perusahaan pelayaran terhadap layanan jasa reparasi kapal di galangan kapal Jawa Timur yang mencakup empat variabel yaitu biaya reparasi, mutu pekerjaan, waktu reparasi, serta pelayanan dan fasilitas. Kedua, dilakukan analisis komponen galangan kapal yang mempengaruhi layanan jasa reparasi sehingga diketahui komponen yang memberikan konstribusi terhadap kepuasan dan penilaian pemilik kapal/perusahaan pelayaran. Ketiga, dihitung besarnya fasilitas yang perlu ditingkatkan berdasarkan keterlambatan dari pekerjaan reparasi. Analisis dilakukan dengan menggunakan metode statistika deskriftif dan pembobotan dari setiap variabel yang dinilai. Hasil analisis menunjukan bahwa kedelapan galangan kapal di Jawa Timur yang dibagi kedalam tiga kategori berdasarkan kapasitasnya menunjukan perlu dilakukan peningkatan komponen penunjang layanan jasa reparasi kapal. Galangan kapal kategori A perlu meningkatkan fasilitas konstruksi sebesar $97 \%$ dan fasilitas bengkel outfitting sebesar $89 \%$. Galangan kapal kategori B perlu meningkatkan fasilitas konstruksi sebesar $85,4 \%$, fasilitas bengkel mesin sebesar $76,92 \%$, fasilitas bengkel outfitting pipa sebesar $42,11 \%$, fasilitas bengkel kayu sebesar $94,74 \%$, fasilitas bengkel listrik sebesar $\mathbf{5 7 , 1 4 \%}$, dan faslitas bengkel fashar sebesar $100 \%$. Sedangkan galangan kapal kategori $\mathrm{C}$, fasilitas dengan peningkatan sebesar $100 \%$ yaitu faslitas docking, fasilitas lifting, dan fasilitas workshop, untuk fasilitas pendukung perlu ditingkatkan sebesar $60 \%$.
\end{abstract}

Kata Kunci-Peningkatan Layanan, Reparasi Kapal, Galangan Kapal, Jawa Timur.

\section{PENDAHULUAN}

$\mathrm{S}$ ETIAP kapal yang berlayar harus selalu dalam keadaan layak yang memenuhi standar klasifikasi dan statutory. Sehingga diperlukan perawatan (maintenance) dan perbaikan/reparasi agar kapal selalu dalam kondisi layak. Perawatan dan perbaikan tersebut dilakukan di galangan kapal.

Jasa reparasi atau perbaikan diberikan galangan kapal atas permintaan pemilik kapal atau perusaahaan perlayaran dengan adanya harapan reparasi dan alur bisnisnya sesuai dengan permintaan. Namun berdasarkan penelitian yang dilakukan oleh Mangoloi M. Siallagan [1] adanya gap kepuasan pelanggan terhadap pelayanan jasa reparasi yang diberikan galangan kapal disebutkan sebanyak 24\% responded yang merupakan pemilik kapal/perusaahaan pelayaraan menyatakan bahwa galangan kapal tidak tepat waktu, 24\% responded menyatakan biaya reparasi mahal, $20 \%$ responded menyatakan hasil reparasi tidak sesuai dengan keinginan pelanggan, $12 \%$ responded menyatakan prosedur reparasi rumit dan berbelit-belit, $10 \%$ pelayanan yang diharapkan pelanggan tidak memuaskan, dan $10 \%$ responded menyatakan survey kerusakan kapal tidak dilaksanakan oleh galangan kapal.

Selain itu berdasarkan penelitian Abdul Rahaman [2] dengan menggunakan metode Qualify Function Deployment (QFD) adanya kesenjangan tentang persepsi pelanggan terhadap atribut kepuasan pelayanan reparasi galangan kapal yaitu meliputi pelayanan galangan kapal sebesar -0.91 , biaya reparasi sebesar -1.05 , kesesuain dengan repair list sebesar 1.05, ketepatan jadwal sebesar -1.96, dan kesesuain dengan biro klasifikasi sebesar -1.58.

Jawa Timur sebagai salah satu daerah dengan banyaknya perusahaan galangan kapal menjadi suatu perhatian khusus dimana perusahaan galangan kapal sangat bervariasi mulai dari yang kapasitas kecil sampai dengan kapasitas besar. Maka pada penelitian ini akan dilakukan analisis peningkatan pelayanan jasa reparasi kapal untuk galangan kapal yang ada di daerah Jawa Timur terkait kepuasan dan persepsi pelanggan yaitu pemilik kapal/ perusahaan pelayaran untuk mengetahui aspek layanan jasa reparasi apa saja di galangan kapal yang harus ditingkatkan. Dari analisis tersebut akan diubah kedalam bentuk teknis peningkatan aspek-aspek layanan jasa reparasi kapal di galangan kapal tersebut dengan tujuan untuk memenuhi harapan pemilik $\mathrm{kapal} /$ perusahaan pelayaran.

\section{TINJAUAN PUSTAKA}

\section{A. Pelanggan}

Pelanggan adalah stakeholder yang menjadi tujuan akhir dari produk yang dikeluarkan suatu perusahaan. Bahkan dalam bukunya "Balanced Scorecard" Robert S. Kaplan dan David P Norton memasukan perspektif pelanggan untuk mengukut konerja perusahaan selain pengukuran tradisional berdasarkan kesehatan laporan keuangan perusahaan. Robert S. Kaplan dan David P Norton meninjau kesehatan dan kinerja perusahaan melalui empat perspektif yaitu perspektif finansial, perspektif pelanggan, perspektif bisnis internal dan 
perspektif pembelajran dan pertumbuhan. Sehingga, pelanggan merupakan perspektif penting dan perushaan harus selalu berusaha untuk memuaskan pelanggan.

\section{B. Kepuasan Pelanggan}

Setelah melakukan pembelian suatu produk, pelanggan akan mengalami tngkat kepuasan atau ketidakpuasan terhadapt produk yang dia beli. Menurut Kotler [3] dalam bukunya Marketing Management kepuasan pelanggan adalah perasaan senang atau kecewa seseorang yang merupakan hasil perbandingan dari persepsi kinerja produk dan harapannya [3]. Kepuasan pelanggan masih menjadi perspektif yang penting, hal ini dikarenakan jika pelanggan merasa puas terhadap barang atau jasa yang dia beli bisa membuat bisnis di masa mendatang lebih baik. Robert $\mathrm{S}$. Kaplan dan David P. Norton mengukur perspektif pelanggan berdasarkan atribut produk/jasa yang terdiri dari fungsionalitas produk/jasa, haga, mutu, dan waktu. Namun, menurut Sugiarto dan Sudjana [3] secara umum terdapat lima driver kepuasan pelanggan yaitu kualitas produk, harga, kualitas layanan, emotional factor, dan kemudahan.

\section{Kesenjangan Kualitas Pelayanan}

Kepuasan pelanggan merupakan salah satu hal terpenting bagi suatu perusahaan. Hal tersebut dapat menilai kualitas dari suatu produk barang atau jasa yang dikeluarkan oleh perusahaan tersebut. Pelanggan memiliki harapan bahwa produk barang atau jasa yang ditawarkan oleh perusahaan akan sebanding dengan pengorbanan yang akan dikeluarkan oleh pelanggan. Sehingga analisis kepuasan pelanggan terhadap produk yang dikeluarkan oleh suatu perusahaan sangatlah penting.

Model yang dapat dipergunakan untuk menganilisi kualitas pada produk suatu jasa tergantung pada tujuan analisis, jenis perusahaan, dan situasi pasar [3]. Adapun model-model tersebut yaitu:

1. Kesenjangan antara pelanggan dan persepsi manajemen.

2. Kesenjangan antara persepsi manajemen terhadap harapan pelanggan dan spesifikasi kualitas jasa.

3. Kesenjangan antara spesifikasi kualitas jasa dan penyampaian jasa.

4. Kesenjangan antara penyampaian jasa dan komunikasi internal.

5. Kesenjangan antara jasa yang dirasakan dan jasa yang diharapkan).

Sehingga bisa diartikan bahwa kesenjangan merupakan ketidak sesuaian antara pelayanan yang dipersepsikan (perceived service) dan pelayanan yang diharapkan (expected service).

\section{Galangan Kapal}

Galangan kapal (shipyard) adalah sebuah tempat di perairan yang memiliki fungsi untuk melakukan pembangunan kapal baru (new building), perbaikan kapal atau reparasi kapal, dan pemeliharaan kapal (maintenance). Pada proses pembuatan kapal baru, di galangan kapal dapat dilakukan kegiatan desain, pembangunan konstruksi kapal, instalasi peralatan dan permesinan, pengecekan, test kelayakan, hingga kapal tersebut dinyatakan layak beroperasi sehingga bisa dilakukan proses delivery. Sedangkan untuk reparasi dan pemeliharaan kapal biasanya dilakukan kegiatan meliputi perbaikan konstruksi, perbaikan atau penggantian permesianan dan peralatan, perawatan main engine dan perlengkapan keselamatan.

Galangan kapal terutama di Indonesia dapat dibagi menjadi tiga jenis [5] yaitu:

1. Building dock shipyard yaitu galangan kapal yang hanya melakukan pembangunan kapal baru.

2. Repair dock shipyard yaitu galangan kapal yang hanya melakukan reparasi dan pemeliharaan kapal.

3. Building and repair shipyard yaitu galangan kapal yang melakukan pembangunan kapal baru, reparasi dan permeliharaan kapal

\section{E. Reparasi Kapal}

Reparasi sebuah kapal merupakan proses memperbaiki atau mengganti bagian-bagian kapal yang sudah tidak layak dan tidak memenuhi standar minimal kelayakan untuk berlayar baik dari peraturan statutory maupun kelas. Reparasi sendiri pada umumnya menyangkut tiga hal yaitu, badan kapal, permesinan kapal, dan outfitting. Dari ketiga hal tersebut biasanya dilakukan perbaikan untuk komponen yang masih bisa digunakan atau dilakukan penggantian bagi komponen yang benar-benar sudah tidak memenuhi rules and regulation.

\section{METODOLOGI PENELITIAN}

\section{A. Studi Pustaka dan Studi Lapangan}

Pada tahap ini dilakukan studi literature dan studi lapangan terkait:

a. Bisnis proses pekerjaan reparasi kapal.

b. Peningkatan kualitas layanan jasa reparasi di industri perkapalan.

c. Persepsi pihak perusahaan pelayaran kepada galangan kapal terkait layanan jasa reparasi kapal.

\section{B. Penerjemahan Variabel-variabel Layanan Jasa Reparasi Kapal}

Penerjemahan variable-variabel layanan jasa reparasi dilakukan untuk langkah pengumpulan data. Aspek-aspek yang menjadi pokok dari bisnis layanan jasa reparasi kapal dikelompokan dan selanjutnya dilakukan pembuatan kuesioner dan daftar pertanyaan wawancara.

\section{Pengumpulan Data}

Pengumpulan data dilakukan dengan dua metode yaitu metode wawancara dan kuesioner. Data-data yang dibutuhkan yaitu:

a. Persepsi konsumen terkait variable-variabel layanan jasa reparasi kapal

b. Harapan konsumen terhadap layanan jasa reparasi kapal.

\section{Evaluasi}

Setelah pengumpulan data dilakukan analisis dan dilakuakan penerjemahaan data-data dari suara responden yaitu ship owner atau perusahaan pelayaran kedalam tingkat 
kepuasan dan bentuk teknis variabel apa saja yang yang harus ditingkatkan galangan kapal dari data-data tersebut sehingga memungkinkan untuk peningkatan layanan jasa reparasi kapal di galangan kapal tersebut.

\section{E. Penyusunan Laporan Penelitian}

Pembuatan laporan dari hasil penelitian.

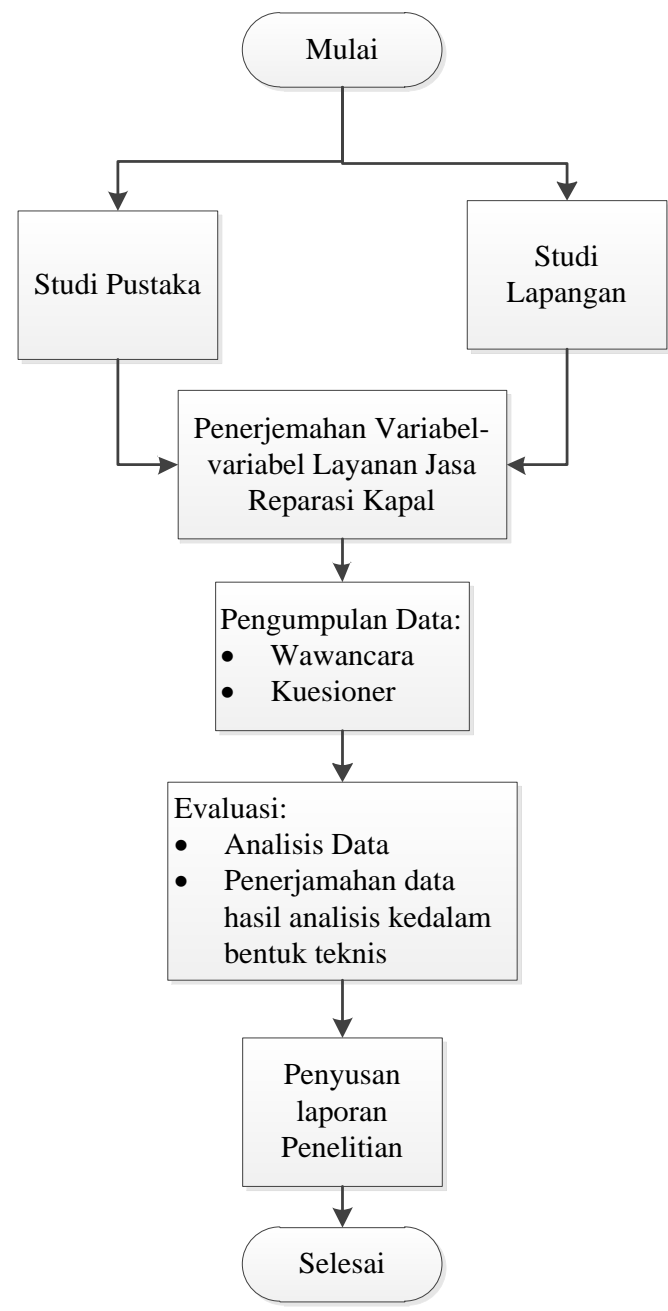

Gambar 1. Alur Penelitian

Pada Gambar 1 ditunjukan flowchart dari penelitian secara garis besarnya.

\section{PENGOLAHAN DATA}

\section{A. Penentuan Populasi dan Sampel}

Sampel dan populasi dari penelitian ini yaitu sebagai berikut:

a. Penentuan Populasi

Populasi dari responden dari penelitian ini adalah perusahaan pelayaran atau pemilik kapal yang pernah menggunakan layanan jasa reparasi kapal di galangan kapal Jawa Timur. Populasi tidak dibatasi oleh jenis kapal yang pernah di reparasi.

b. Pengambilan Sampel

Pengambilan sampel dilakukan menggunakan teknik simple random sampling, dimana pengambilan anggota sampel dari populasi dilakukan secara acak tanpa memperhatikan strata yang ada dalam populasi. Sampel yang diambil dalam penelitian ini sebanyak 6 perusahaan pelayaran/pemilik kapal

\section{B. Galangan Kapal di Jawa Timur}

Galangan kapal kapal di daerah Jawa Timur yang menjadi pokok penelitian ada 8 galangan kapal yang ditunjuk oleh perusahaan pelayaran yang dibagi kedalam tiga kategori berdasarkan kapasitasnya.

a. Galangan Kapal Kategori A

Galangan kapal yang termasuk kategori A yaitu galangan kapal yang memiliki kapasitas lebih dari 10.000 DWT, yakni PT. PAL Indonesia (Persero).

b. Galangan Kapal Kategori B

Galangan kapal yang termasuk kategori B yaitu galangan kapal yang memiliki kapasitas dibawah 10.000 DWT, yakni PT. Dok dan Perkapalan Surabaya dan PT. Dumas Tanjung Perak Shipyard.

c. Galangan Kapal Kategori C

Galangan kapal yang termasuk ke dalam galangan kapal kategori C yaitu galangan kapal yang memiliki kapasitas dibawah 5.000 DWT, yaitu Galangan PELNI Surya, PT. Adiluhung Saranasegara Indonesia, PT. Ben Santosa, PT. Indonesia Marina Shipyard, dan PT. Najatim.

\section{PERSEPSI PENGGUNA LAYANAN JASA REPARASI KAPAL}

\section{A. Analisis Variabel-variabel Layanan Jasa Reparasi Kapal di Galangan Kapal Kategori A}

Biaya reparasi di galangan kapal ini termasuk mahal, dengan kualitas cukup bagus. Sebanyak 33,33\% dari jumlah responden menilai kualitas reparasi kapal untuk hampir semua jenis reparasi di galangan kapal kategori A buruk dan kepuasan responden (pemilik kapal) terhadap pekerjaan reparasi kapal di galangan kapal ini rendah. Pengguna layanan jasa reparasi kapal yakni pemilik kapal/perusahaan pelayaran menginginkan peningkatan kualitas reparasi sesuai standar reparasi yang ada sehingga dapat dilihat dengan berkurangnya reworking dan comment perbaikan dari pihak klasifikasi terutama untuk pekerjaan welding.

Waktu reparasi kapal di galangan kapal kategori A memiliki nilai rata-rata 4,667 dari skala 5. Nilai tersebut menunjukan reparasi kapal di galangan kapal ini hampir selalu terlambat. Sehingga perbaikan waktu reparasi kapal sangat penting dalam layanan jasa reaprasi kapal di galangan kapal ini.

Nilai rata-rata dari waktu yang dibutuhkan pemilik kapal untuk melakukan permintaan docking space untuk keperluan layanan jasa reparasi kapal yaitu 4,33 dari skala 5. Arti dari nilai tersebut yaitu rata-rata waktu yang dibutuhkan pemilik kapal untuk melakukan permintaan layanan jasa reparasi kapal dibutuhkan waktu lebih dari 4 minggu. Hal ini disebabkan oleh prosedur yang rumit dan proses negosiasi yang bahkan bisa mencapai lebih dari 50 hari untuk kapal yang menggunakan proses lelang.

Fasilitas reparasi kapal di galangan kapal ini berdasarkan penilaian pengguna layanan jasa reparasi kapal memiliki nilai rata-rata 3 dari skala 4 , kecuali fasilitas crane yaitu nilai rata-rata kondisi fasilitas crane adalah 2,67. Artinya kondisi fasilitas reparasi dalam kondisi baik kecuali crane.

Selain itu sebanyak $100 \%$ responden menyatakan biaya 
reparasi mahal, 66,66\% responden menyatakan reparasi kapal selalu terlambat dengan rentang keterlambatan paling tinggi $41 \%-60 \%$ pada reparasi konstruksi sedangkan yang jenis reparasi lainnya $21 \%$ - 40\%, dan $33,33 \%$ responden menyatakan tanggapan terhadap komplain buruk.

\section{B. Analisis Variabel-variabel Layanan Jasa Reparasi Kapal di Galangan Kapal Kategori B}

Berdasarkan hasil analisis dan data yang didapatkan dari hasil kuesioner dapat dijelaskan nilai dan kategori pada setiap item dari variabel biaya reparasi untuk galangan kapal yang termasuk ke dalam kategori B yaitu sebanyak 100\% dari jumlah responden menyatakan biaya reparasi di galangan kapal ini mahal dan sistem pembayaran biaya reparasi di galangan kapal ini bagus. Sedangkan untuk nilai rata-ratanya 2 dari skala 4 untuk biaya reparasi dan 3 dari skala 4 untuk sistem pembayaran biaya reparasi.

Variabel waktu reparasi dinilai berdasarkan tingkat keterlambatan pekerjaan reparasi kapal yang dialami oleh pemilik kapal selama menggunakan layanan jasa reparasi di galangan kapal ini. Berdasarkan penilaian responden (pemilik kapal), sebanyak $50 \%$ responden menyatakan reparasi kapal di galangan kapal ini "jarang" terlambat, $33,33 \%$ responden menyatakan reparasi kapal di galangan kapal ini "sering" terlambat, dan $16,67 \%$ responden menyatakan reparasi digalangan kapal ini "selalu" terlambat, untuk nilai rata-ratanya 3,67 dari skala 5 .

Berdasarkan data yang didapatkan dan hasil analisis, sebanyak 83,33\% dari jumlah responden mengungkapkan bahwa di galangan kapal kategori B memerlukan waktu 4 minggu untuk melakukan permintaan docking space untuk keperluan reparasi kapal. Sedangkan $16,67 \%$ responden mengungkapkan memerlukan waktu 8 minggu termasuk waktu negosiasi yang memakan waktu 50 hari.

Hasil analisis lainnya sebanyak $33,33 \%$ responden menyatakan kualitas reparasi konstruksi buruk dan 16,67\% responden tidak puas terhadap kualitas tersebut, $16,67 \%$ responden menyatakan reparasi kapal selalu terlambat dengan rentang keterlambatan paling tinggi $41 \%$ - $60 \%$ pada reparasi konstruksi sedangkan yang jenis reparasi lainnya $21 \%$ - 40\%, 16,67\% responden menyatakan fasilitas bengkel mesin kurang memadai dan 33,33\% responden menyatakan fasilitas crane kurang memadai, dan 33,33\% responden menyatakan tanggapan terhadap komplain buruk.

\section{Analisis Variabel-variabel Layanan Jasa Reparasi Kapal di Galangan Kapal Kategori C}

Berdasarkan hasil analisis dan data yang didapatkan dari hasil kuesioner, sebanyak $80 \%$ dari jumlah responden menyatakan harga atau biaya reparasi di galangan kapal kategori C mahal, dan 20\% responden lainnya menyatakan murah. Sedangkan untuk sistem pembayaran biaya reparasi, $100 \%$ responden menyatakan sistem pembayaran biaya reparasi di galangan kapal ini bagus. Sedangkan nilai rataratanya 2,2 dari skala 4 untuk biaya reparasi dan 3 dari skala 4 untuk sistem pembayaran biaya reparasinya.

Waktu reparasi kapal di galangan kapal kategori C sama dengan galangan kapal kategori lainnya, yaitu pengguna layanan jasa reparasi kapal (pemilik kapal/perusahaan pelayaran) menilai tingkat keterlambatan pekerjaan reparasi di galangan kapal ini. Berdasarkan analisis dan data yang didapatkan $80 \%$ responden menyatakan reparasi kapal di galangan kapal kategori C jarang terlambat akan tetepi $20 \%$ responden menyatakan sering terlambat dengan nilai rataratanya 3,4 dari skala 5 jarang terjadi keterlambatan.

Selain itu sebanyak $80 \%$ responden menyatakan biaya reparasi mahal, $40 \%$ responden menyatakan kualitas reparasi konstruksi buruk terutama pada coating dan $80 \%$ responden untuk kualitas reparasi hull equoment and outfitting, $80 \%$ responden hanya cukup puas terhadap kualitas tersebut, $20 \%$ responden menyatakan reparasi kapal sering terlambat dengan rentang keterlambatan paling tinggi untuk setiap jenis reparasi yaitu 21\% - 40\%, 60\% responden menilai fasilitas docking undocking, bengkel mesin, dan $80 \%$ responden untuk crane menyatakan kondisinya buruk, $40 \%$ responden menilai fasilitas bengkel mesin dan $80 \%$ responden untuk fasilitas crane menyatakan kurang memadai, dan $33,33 \%$ responden menyatakan keselamatan kerja di galangan kapal buruk

\section{VARIABEL LAYANAN JASA REPARASI KAPAL YANG HARUS DITINGKATKAN}

Berdasarkan data-data dan anilisis dari masing-masing penilaian variabel layanan jasa reparasi kapal di galangan kapal kategori A keluar skor atau nilai dari setiap variabel. Nilai tersebut kemudian dirata-rata antara penilaian aspek yang berkaitan. Contohnya mutu pekerjaan dengan dua bagian yang dinilai yaitu kualitas pekerjaan dan kepuasan responden (pemilik kapal/perusahaan pelayaran) terhadap layanan jasa reparasi kapal di galangan ini.

Peningkatan dibagi kedalam 4 tingkatan prioritas.

- Prioritas 1 yaitu komponen yang memiliki nilai rata-rata mendekati batas bawah, yang artinya komponen tersebut harus segerra dilakukan perbaikan dan peningkatan.

- Prioritas 2 yaitu komponen yang memiliki nilai rata-rata kedua dari batas bawah, yang artinya komponen tersebut harus segera ditingkatkan, namun tidak terlalu mendesak.

- Prioritas 3 yaitu komopen yang memiliki nilai rata-rata berada diatas nilai tengah, artinya komponen tersebut sudah melewati titik aman, hanya saja peningkatan teteap harus dilakukan karena belum mencapai keadaan yang diinginkan.

- Prioritas 4 adalah komponen yang memiliki nilai rata-rata mendekati batas atas sehingga peningkatan atau perbaiakan tidak harus dilakukan akan tetapi peningkatan atau perbaikan komponen tersebut bisa tetap dilakukan.

\section{A. Variabel-variabel Layanan Jasa Reparasi yang Harus Ditingkatkan di Galangan kapal Kategori A}

Komponen yang mendukung mutu dan waktu pekerjaan hanya komponen keahlian yang menempati prioritas 2 sedangkan fasilitas menempati prioritas 3. Tidak ada komponen yang menempati prioritas 1 dan prioritas 4 , yang artinya tidak ada komponen yang harus sesegera mungkin diperbaiki dan ditingkatkan, dan tidak ada juga komponen yang tidak harus ditingkatkan seperti ditunjukan Tabel 1. 
Prioritas Peningkatan Komponen Galangan Kapal Kategori

\begin{tabular}{|l|c|}
\hline \multicolumn{1}{|c|}{ Item } & Prioritas \\
\hline Prosedur & Prioritas 2 \\
\hline Keahlian Pekerjaan Reparasi & Prioritas 2 \\
\hline Fasilitas Reparasi & Prioritas 3 \\
\hline Pelayanan & Prioritas 2 \\
\hline Kondisi Galangan Kapal & Prioritas 3 \\
\hline Keselamatan Kerja & Prioritas 3 \\
\hline
\end{tabular}

Berdasarkan penilaian pengguna layanan jasa reparasi,

keahlian yang menjadi prioritas harus ditingkatkan yaitu:

- keahlian welding,

- keahlian blasting,

- keahlian coating,

- keahlian reparasi permesinan,

- kehlian reparasi perpipaan,

- keahlian reparasi hull equipment and outfitting, dan

- keahlian reparasi akomodasi dan interior.

Fasilitas reparasi kapal yang perlu ditingkatkan pada prioritas 3 yaitu:

- Fasilitas bengkel fabrikasi

- Fasilitas bengkel mesin,

- Fasilitas bengkel outfitting,

- Fasilitas bengkel listrik, dan

- Fasilitas crane.

Sedangkan pelayanan yang harus ditingkatkan pada prioritas 2 yaitu:

- Tanggapan galangan terhadap komplain konsumen

- Fasilitas ruangan untuk pihak owner

- Fasilitas penunjang yaitu kantin dan toilet.

- Pengaturan limbah reparasi.

B. Variabel-variabel Layanan Jasa Reparasi yang Harus Ditingkatkan di Galangan kapal Kategori B

Komponen-komponen yang mempengaruhi variabelvariabel layanan jasa reparasi kapal di galangan kategori B beserta prioritas peningkatannya. Diperlihatkan bahwa komponen yang mendukung mutu dan waktu pekerjaan dan hampir seluruh komponen menempati prioritas. Tidak ada komponen yang menempati prioritas 1 dan prioritas 4 , yang artinya tidak ada komponen yang harus sesegera mungkin diperbaiki dan ditingkatkan, dan tidak ada juga komponen yang tidak harus ditingkatkan seperti ditunjukan Tabel 2.

Tabel 2.

Prioritas Peningkatan Komponen Galangan Kapal Kategori B

\begin{tabular}{|l|c|}
\hline \multicolumn{1}{|c|}{ Item } & Prioritas \\
\hline Prosedur & Prioritas 2 \\
\hline Keahlian Pekerjaan Reparasi & Prioritas 2 \\
\hline Fasilitas Reparasi & Prioritas 2 \\
\hline Pelayanan & Prioritas 2 \\
\hline Keselamatan Kerja & Prioritas 3 \\
\hline
\end{tabular}

Peningkatan keahlian menjadi kunci utama dari peningkatan mutu pekerjaan. Sehinga diperlukannya peningkatan keahlian SDM di galangan kapal kategori B sejalan dengan berubahnya teknologi kapal dan teknologi reparasi kapal. Keahlian yang harus ditingkatkan berdasrkan jenis pekerjaan reparasi yaitu sebagai berikut:

- Keahlian reparasi konstruksi (welding, blasting, coating).

- Keahlian reparasi sistem propulsi.

- Keahlian reparasi instalasi listrik.
- Keahlian reparasi permesinan.

- Keahlian reparasi perpipaan.

- Keahlian reparasi hull equipment dan outfitting

Fasilitas reparasi kapal yang perlu ditingkatkan pada prioritas 2 yaitu:

- Fasilitas bengkel fabrikasi

- Fasilitas bengkel mesin,

- Fasilitas bengkel outfitting,

- Fasilitas bengkel listrik, dan

- Fasilitas crane.

Sedangkan pelayanan yang harus ditingkatkan pada prioritas 2 yaitu:

- Tanggapan galangan terhadap komplain konsumen.

- Fasilitas ruangan untuk pihak owner.

- Kondisi galangan kapal termasuk kebersihan dan kerapihan.

- Fasilitas penunjang yaitu kantin dan toilet.

- Pengaturan limbah reparasi.

C. Variabel-variabel Layanan Jasa Reparasi yang Harus Ditingkatkan di Galangan kapal Kategori C

Galangan kapal kategori C perlu meningkatkan semua komponen yang mendukung variable layanan jasa reparasi kapal dimana semuanya menempati prioritas 2 . Hal tersebut berarti semua komponen tersebut harus ditingkatkan dan diperbaharui. Tidak ada komponen yang menempati prioritas 1 dan prioritas 4, yang artinya tidak ada komponen yang harus sesegera mungkin diperbaiki dan ditingkatkan, dan tidak ada juga komponen yang tidak harus ditingkatkan seperti ditunjukan Tabel 3.

Tabel 3.

Prioritas Peningkatan Komponen Galangan Kapal Kategori B

\begin{tabular}{|l|c|}
\hline \multicolumn{1}{|c|}{ Item } & Prioritas \\
\hline Prosedur & Prioritas 2 \\
\hline Keahlian Pekerjaan Reparasi & Prioritas 2 \\
\hline Fasilitas Reparasi & Prioritas 2 \\
\hline Pelayanan & Prioritas 2 \\
\hline
\end{tabular}

Diperlukannya peningkatan keahlian SDM untuk meningkatkan mutu pekerjaan reparasi di galangan kapal kategori C. Keahlian yang harus ditingkatkan berdasarkan jenis pekerjaan reparasi yaitu sebagai berikut

- Keahlian reparasi konstruski (welding, blasting, coating).

- Keahlian reparasi sistem propulsi.

- Keahlian reparasi instalasi listrik.

- Keahlian reparasi perpipaan.

- Keahlian reparasi hull equipment and outfitting

Fasilitas reparasi kapal yang perlu ditingkatkan pada prioritas 2 yaitu:

- Fasilitas bengkel fabrikasi

- Fasilitas bengkel mesin,

- Fasilitas bengkel outfitting,

- Fasilitas bengkel listrik, dan

- Fasilitas crane.

Sedangkan pelayanan yang harus ditingkatkan pada prioritas 2 yaitu:

- Tanggapan galangan terhadap komplain konsumen.

- Fasilitas ruangan untuk pihak owner.

- Kondisi galangan kapal termasuk kebersihan dan kerapihan.

- Fasilitas penunjang yaitu kantin dan toilet. 
- Keselamatan kerja.

- Pengaturan limbah reparasi.

\section{FASILITAS GALANGAN KAPAL YANG HARUS DITINGKATKAN}

\section{A. Fasilitas Reparasi di Galangan Kapal Kategori A}

Hasil perhitungan seperti menunjukan bahwa peningkatan fasilitas layanan jasa reparasi paling tinggi yaitu pada fasilitasn bengkel konstruksi yaitu bengkel yang melayani pekerjaan reparasi konstruksi dengan nilai 96,77\%. Hal ini disebabkan rata-rata keterlambatan pengerjaan reparasi konstruksi yang cukup tinggi dibandingkan dengan jenis reparasi lainnya yang mencapai angka 60\%. Dari angka 97 tersebut, penambahan fasilitas terjadi terutama pada peralatan cutting, marking, dan welding.

\section{B. Fasilitas Reparasi di Galangan Kapal Kategori B}

Fasilitas yang harus ditingkatkan di galangan kapal kategori B menempati angka lebih dari $80 \%$ dari fasilitas yang ada. Fasilitas yang perlu ditingkatkan tersebut yaitu fasilitas bengkel konstruksi, kayu, dan fashar. Peningkatan dengan presentase paling rendah yaitu fasilitas bengkel pipa dengan presentase $42,11 \%$, sedangkan yang lainnya berada direntang $50 \%-80 \%$.

\section{Fasilitas Reparasi di Galangan Kapal Kategori C}

Perhitungan peningkatan fasilitas kapal di galangan kapal ini hanya berdasarkan kuantitas dari fasilitas reparasi yang tersedia. Fasilitas yang paling mendapatkan persentse paling tinggi peningkatannya yaitu fasilitas docking undocking, fasilitas angkut (lifting equipment), dan fasilitas workshop. Semua fasilitas digalangan kapal ini mendapat prioritas peningkatan prioritas 2 dari 4 tingkat prioritas yang artinya fasilitas di galangan kapal ini masih kurang. Dari hasil perhitungan terdapat fasilitas yang harus ditingkatkan $100 \%$ dari fasilitas yang tersedia. Fasilitas terebut yaitu fasilitas docking undocking, fasilitas lifting equipment, dan fasilitas workshop. Sisanya selain fasilitas tadi peningkatannya cukup $60 \%$ dari fasilitas yang tersedia yaitu fasilitas penunjang salah satu contohnya listrik.

\section{KESIMPULAN/RINGKASAN}

. 1. Galangan kapal kategori A (kapasitas diatas 10.000 DWT) yaitu PT. PAL Indonesia (Persero). Penilaian pemilik $\mathrm{kapal} /$ perusahaan pelayaran (responden) terhadap galangan kapal kategori A yaitu peningkatan komponen galangan kapal menempati prioritas 2 dan 3 dari 4 tingkat prioritas dengan penignkatan fasilitas yang harus dilakukan berdasarkan keterlambatan yaitu pada rentang $89 \%-97 \%$.

2. Galangan kapal kategori B (kapasitas 5.000-10.000 DWT) yaitu PT. Dok dan Perkapalan Surabaya (Persero) dan PT. Dumas Tanjung Perak Shipyard. Penilaian pemilik $\mathrm{kapal} /$ perusahaan pelayaran (responden) terhadap galangan kapal kategori B yaitu peningkatan komponen galangan kapal menempati prioritas 2 dan 3 dari 4 tingkat prioritas dengan penignkatan fasilitas yang harus dilakukan berdasarkan keterlambatan yaitu pada rentang 42,11\% $100 \%$.

3. Galangan kapal kategori C (kapasitas di bawah 5.000
DWT) yaitu Galangan Surya PELNI, PT. Adiluhung SaranaSegara Indonesia, PT. Ben Santosa, PT. Indonesia Marina Shipyard, dan PT. Najatim. Penilaian pemilik $\mathrm{kapal} /$ perusahaan pelayaran (responden) terhadap galangan kapal kategori B yaitu peningkatan komponen galangan kapal menempati prioritas 2 dari 4 tingkat prioritas dengan penignkatan fasilitas yang harus dilakukan berdasarkan keterlambatan yaitu pada rentang 60\% - 100\%.

\section{UCAPAN TERIMA KASIH}

Tuliskan ucapan terima kasih kepada kedua orang tua atas dukungannya dan kepada Ir. Triwilaswadio Wuruk Pribadi, M.Sc. berserta dosen-dosen bidang studi Industri Perkapalan atas bantuan dan bimbingannya. .

\section{DAFTAR PUSTAKA}

[1] Siallagan, M. M. (2005). Studi Peningkatan Kualitas Layanan Jasa Reparasi di Industri Perkapalan. Surabaya: Institut Teknologi Sepuluh Nopember.

[2] Rahman, A., \& Supomo, H. (2012). Analisa Kepuasan Pelanggan pada Pekerjaan Reparasi Kapal dengan Metode Quality Function Deployment (QFD). ITS, 6.

[3] Sudjana, R., \& Sugiarto. (2007). Ekonomi Mikro Sebuah Kajian Komprehensif. Jakarta: Gramedia Pustaka Utama.

[4] Simamora, B. (2008). Panduan Riset Perilaku Konsumen. Jakarta: Gramedia Pustaka Utama.

[5] Alfa Trans Raya. (2014, November). Shipyard and Docking. Suar Volume 7, p. 2. 